\title{
MODEL PENGENALAN AIR BAGI SISWA TAMAN KANAK-KANAK
}

\section{WATER INTRODUCTION MODEL FOR KINDERGARTEN STUDENTS}

\author{
Nur Sita Utami, Sukadiyanto \\ Universitas Negeri Yogyakarta, Universitas Negeri Yogyakarta \\ nursitautami@gmail.com, sukadiyanto_fik@yahoo.com
}

\begin{abstract}
Abstrak
Penelitian dan pengembangan ini bertujuan menghasilkan model pengenalan air melalui aktivitas bermain bagi siswa TK (Taman Kanak-kanak) kelompok B. Model pengenalan air mengembangkan aspek kognitif, afektif, dan psikomotor yang sesuai dengan kurikulum dan karakteristik siswa TK kelompok B. Model pengenalan air diharapkan digunakan guru dalam penyelenggaraan kegiatan belajar mengajar. Penelitian dan pengembangan melalui 9 tahapan yang mengadaptasi model Dick \& Carey. Hasil penelitian berupa model pengenalan air bagi siswa TK yang terdiri dari 6 permainan, yaitu: (1) bola warna, (2) air tumpah, (3) harta karun, (4) mandi pagi, (5) hewan laut, dan (6) balap donat dan kacang. Model disusun dalam buku pedoman berjudul "Jelajah Air". Berdasarkan penilaian para ahli materi dan guru dapat disimpulkan bahwa model pengenalan air bagi siswa TK sesuai dengan kurikulum dan karakteristik siswa TK kelompok B. Selain itu, model pengenalan air dapat mengembangkan aspek kognitif, afektif, dan psikomotor sehingga layak digunakan dalam pembelajaran TK kelompok B.
\end{abstract}

Kata kunci: model, pengenalan, air, TK

\begin{abstract}
This study aims at delivering water introduction model through playing activities for group B kindergarten students. Water introduction model develops cognitive, affective, psychomotor aspects which are adapted with the curriculum and the characteristics of group B kindergarten students. This model is hopefully used by the teacher in teaching and learning process of group B kindergarten. This study was a research and development conducted in 9 steps by adapting educational research and development according to Dick \& Carey's Model. The result of the study is a water instroduction model for kindergarten students consisting of 6 games, they are: (1) colored-ball game, (2) spilled water game, (3) morning-bath game, (4) sea creatures game, (5) treasure game, and (6) donut and peanut race. Model is compiled in a guidance book entitled "Jelajah Air". According to the experts and teachers, it can be concluded that the water introduction model for kindergarten students is appropriate for kindergarten group B students and in accordance with the curriculum. Moreover, this model can develop cognitive, affective, and psychomotor aspects so that it is feasible for teaching group B kindergarten students.
\end{abstract}

Keywords: model, introduction, water, kindergarten 


\section{Pendahuluan}

Pengenalan air diberikan sebelum anak mempelajari teknik gerak renang. Aktivitas akuatik dalam pengenalan air meliputi gerak dasar, sikap, dan keamanan air untuk mempersiapkan anak belajar teknik gerak renang. Gerak dasar yang dimaksud adalah pondasi gerak untuk belajar renang, yang terdiri atas cara masuk ke air, daya apung tubuh di air, gerakan tungkai, keseimbangan tubuh di air, gerak lengan, dan kontrol nafas. Sikap dasar yang dibentuk melalui aktivitas pengenalan air adalah berani, mematuhi peraturan, dan partisipasi aktif. Pemahaman dasar yang diharapkan dapat dicapai anak melalui aktivitas pengenalan air, yaitu pemahaman terhadap prosedur kelas, peraturan kolam renang, peraturan permainan, instruksi guru, dan pelaksanaan gerak dasar.

Anak usia dini merupakan usia bermain sehingga aktivitas pengenalan air yang diberikan merupakan aktivitas bermain. Secara umum, anak menyukai bermain air, namun beberapa anak belum memiliki kesiapan mental untuk bermain di lingkungan air yang luas seperti kolam renang. Hal tersebut terjadi terutama pada anak yang tinggal di daerah perkotaan sehingga jarang beraktivitas di laut, danau, atau sungai.

Lingkungan air yang luas seperti kolam renang, menjadi salah satu faktor anak mengalami rasa khawatir dan tidak percaya diri beraktivitas di air. Pendekatan melalui aktivitas bermain diperlukan bagi anak dalam pengenalan air untuk menumbuhkan rasa aman dan nyaman beraktivitas di air. Pengenalan air bagi anak melalui pendekatan drill tanpa aktivitas bermain harus dihindari agar anak tidak merasa tertekan. Anak yang merasa tertekan akan memberikan efek negatif pada perkembangan psikologis anak. Menurut Miller \& Almon (2009, p.43) bahwa anak yang berada di bawah tekanan kemungkinan akan mengalami peningkatan agresi dan kemarahan.

Pengenalan air melalui pembelajaran renang sudah menjadi program di beberapa TK (Taman Kanak-kanak). Pelaksanaan pembelajaran menggunakan kolam renang milik sekolah bagi TK yang memiliki fasilitas kolam renang. TK yang belum memiliki kolam renang pada periode waktu tertentu menyewa kolam renang umum. Hal tersebut mengindikasikan bahwa guru TK maupun orang tua murid menyadari kebutuhan mengenalkan siswa pada lingkungan bermain di air. Ketika peneliti melakukan wawancara terhadap salah seorang guru TK terdapat pernyataan, "Permainan di air diperlukan anak untuk melatih kepercayaan diri, selain itu anak dapat bermain secara menyenangkan (RW)". Guru merasa perlu menyelenggarakan aktivitas bermain di air pada siswa untuk merangsang perkembangan sosial emosional.

Muatan kurikulum TK bidang pengembangan fisik motorik memungkinkan diadakan pengembangan pembelajaran di air. Pelaksanaan pembelajaran dalam kurikulum tidak melarang pembelajaran fisik motorik diadakan di kolam renang. salah satu tingkat pencapaian perkembangan dalam kurikulum TK adalah melakukan gerak tubuh secara terkoordinasi untuk melatih kelenturan, keseimbangan, dan kelincahan (Kemdiknas, 2010, p.12). Aktivitas pengenalan air mengandung unsur kelenturan, keseimbangan, dan kelincahan sehingga dapat menjadi salah satu alternatif pengembangan permainan.

Anak yang berani bermain di air memudahkan orang tua ketika mengajarkan cara mandi, terutama ketika anak harus mengguyur kepala untuk mencuci rambut. Manfaat lain yang dirasakan orang tua adalah dapat membawa anak berekreasi di wahana wisata air, seperti water boom atau kolam renang. Anak sudah mengenal peraturan beraktivitas di kolam renang ketika bermain di air sehingga memudahkan orang tua dalam memberikan pengetahuan tentang aktivitas yang aman.

Berdasarkan kenyataan tersebut, maka dilakukan analisis kebutuhan pengenalan air bagi siswa TK. Observasi dilakukan pada tiga TK di Kota Yogyakarta dan dua TK di Sleman selama bulan Oktober-November 2012. Hasil observasi diperdalam dengan wawancara terhadap guru yang bertanggung jawab dalam pelaksanaan pembelajaran akuatik di masing-masing TK.

Hasil observasi dan wawancara peneliti terkait pelaksanaan pengenalan air di TK dirangkum dalam tabel 1, 2, 3, 4, dan 5 . 
Tabel 1. Hasil Observasi Kolam Renang TK

\begin{tabular}{|c|c|c|c|}
\hline No & Nama Sekolah & $\begin{array}{l}\text { Kolam } \\
\text { Renang }\end{array}$ & $\begin{array}{c}\text { Ukuran } \\
\text { Kolam } \\
\text { Renang }\end{array}$ \\
\hline 1 & $\begin{array}{l}\text { TK Negeri Pem- } \\
\text { bina Yogyakarta }\end{array}$ & $\begin{array}{c}\text { Milik } \\
\text { sekolah }\end{array}$ & $6 \times 8 \mathrm{~m}$ \\
\hline 2 & $\begin{array}{l}\text { TK Negeri } 2 \\
\text { Yogyakarta }\end{array}$ & $\begin{array}{c}\text { Milik } \\
\text { sekolah }\end{array}$ & $3 \times 5 \mathrm{~m}$ \\
\hline 3 & $\begin{array}{l}\text { TK Pedagogia FIP } \\
\text { UNY }\end{array}$ & $\begin{array}{c}\text { Milik } \\
\text { sekolah }\end{array}$ & $5 \times 7 \mathrm{~m}$ \\
\hline 4 & $\begin{array}{l}\text { Kangaroo } \\
\text { Preschool }\end{array}$ & $\begin{array}{l}\text { Milik } \\
\text { sekolah }\end{array}$ & $6 \times 9 \mathrm{~m}$ \\
\hline 5 & $\begin{array}{l}\text { Bambini } \\
\text { Montessori }\end{array}$ & $\begin{array}{c}\text { Milik } \\
\text { sekolah }\end{array}$ & $4 \times 6 \mathrm{~m}$ \\
\hline
\end{tabular}

Tabel 2. Hasil Observasi dan Wawancara

Frekuensi dan Status Pembelajaran Akuatik

\begin{tabular}{|c|c|c|c|}
\hline No & $\begin{array}{c}\text { Nama } \\
\text { Sekolah }\end{array}$ & $\begin{array}{c}\text { Frekuensi } \\
\text { Pelaksanaan }\end{array}$ & $\begin{array}{c}\text { Status } \\
\text { Pembelajaran } \\
\text { Akuatik }\end{array}$ \\
\hline 1 & $\begin{array}{l}\text { TK Negeri } \\
\text { Pembina } \\
\text { Yogyakarta }\end{array}$ & $1 \mathrm{x} 1 \mathrm{ming} g \mathrm{u}$ & Ekstra pilihan \\
\hline 2 & $\begin{array}{l}\text { TK Negeri } 2 \\
\text { Yogyakarta }\end{array}$ & $1 \times 1$ minggu & $\begin{array}{c}\text { Muatan lokal } \\
\text { pilihan }\end{array}$ \\
\hline 3 & TK Pedagogia & $1 \times 2$ minggu & Ekstra wajib \\
\hline 4 & $\begin{array}{l}\text { Kangaroo } \\
\text { Preschool }\end{array}$ & $1 \times 1$ minggu & $\begin{array}{l}\text { Muatan lokal } \\
\text { pilihan }\end{array}$ \\
\hline 5 & $\begin{array}{l}\text { Bambini } \\
\text { Montessori }\end{array}$ & $\begin{array}{c}5 \times 1 \\
\text { semester }\end{array}$ & $\begin{array}{l}\text { Pendidikan } \\
\text { jasmani }\end{array}$ \\
\hline
\end{tabular}

Tabel 3. Hasil Observasi dan Wawancara Bentuk Perencanaan Pembelajaran

\begin{tabular}{clc}
\hline No & \multicolumn{1}{c}{ Nama Sekolah } & Bentuk Perencanaan \\
\hline 1 & TK Negeri Pembina & Rencana Kegiatan \\
& Yogyakarta & Semester (RKS) \\
2 & TK Negeri 2 & Rencana Kegiatan \\
& Yogyakarta & Semester (RKS) \\
3 & TK Pedagogia FIP & Rencana Kegiatan \\
& UNY & Semester (RKS) \\
4 & Kangaroo Preschool & Rencana Kegiatan \\
& & Semester (RKS) \\
5 & Bambini Montessori & Rencana kegiatan harian \\
& & (RKH) \\
\hline
\end{tabular}

Tabel 4. Hasil Observasi dan Wawancara Pelaksanaan Model Pengenalan Air

\begin{tabular}{|c|c|c|}
\hline No & Nama Sekolah & $\begin{array}{c}\text { Model Pengenalan } \\
\text { Air }\end{array}$ \\
\hline 1 & $\begin{array}{l}\text { TK Negeri Pembina } \\
\text { Yogyakarta }\end{array}$ & Drill \\
\hline 2 & TK Negeri 2Yogyakarta & Bermain bebas \\
\hline 3 & $\begin{array}{l}\text { TK Pedagogia FIP } \\
\text { UNY }\end{array}$ & Bermain terstruktur \\
\hline 4 & Kangaroo Preschool & $\begin{array}{c}\text { Teknik secara } \\
\text { berulang-ulang }\end{array}$ \\
\hline 5 & Bambini Montessori & Bermain terstruktur \\
\hline
\end{tabular}

Tabel 5. Hasil Observasi dan Wawancara Kuantitas Pengajar, Pengawas, dan Siswa dalam Pelaksanaan Pembelajaran di Air Taman Kanak-kanak

\begin{tabular}{clccccc}
\hline \multirow{2}{*}{ No } & \multirow{2}{*}{ Nama Sekolah } & Pengajar & \multicolumn{2}{c}{ Pengawas } & \multirow{2}{*}{$\boldsymbol{\Sigma}$ Siswa } \\
\cline { 3 - 5 } & & Status & $\boldsymbol{\Sigma}$ & Status & $\boldsymbol{\Sigma}$ & \\
\hline 1 & TK Negeri Pembina Yogyakarta & Guru ekstra & 1 & Guru kelas & 2 & $17-20$ \\
2 & TK Negeri 2 Yogyakarta & - & - & Guru kelas & 2 & 8 \\
3 & TK Pedagogia FIP UNY & Guru ekstra & 3 & - & - & $17-20$ \\
4 & Kangaroo Preschool & Guru kelas & 3 & - & - & 10 \\
5 & Bambini Montessori & Guru Penjas & 1 & Guru kelas & 2 & 10 \\
\hline
\end{tabular}

Pembahasan hasil observasi dan wawancara tentang pelaksanaan pengenalan air di TK sebagai berikut, (1) sekolah tidak mengalami kesulitan mengadakan aktivitas pengenalan air di kolam renang karena memiliki kolam renang dengan ukuran kolam yang cukup memadai, (2) frekuensi pembelajaran akuatik di tiga sekolah adalah 1 kali latihan per minggu, satu sekolah melaksanakan 1 kali latihan per dua minggu, dan satu sekolah menyelenggarakan pembelajaran akuatik 5 kali dalam satu semester. Frekuensi pembelajaran akuatik yang tertulis pada tabel 2 berlaku pada satu kelas atau kelompok. Pengenalan air diberikan setiap awal program pembelajaran akuatik, (3) terdapat dua sekolah membedakan jadwal pembelajaran akuatik antara siswa laki-laki dan perempuan, yaitu TK Negeri Pembina Yogyakarta dan TK Negeri 2 Yogyakarta. Sedangkan, tiga sekolah lainnya menggabungkan siswa laki-laki dan perempuan, (4) status pembelajaran akuatik adalah ekstrakurikuler pilihan di satu sekolah, ekstrakurikuler wajib pada satu sekolah, muatan lokal pilihan pada dua sekolah, dan pembelajaran pendidikan jasmani pada satu sekolah. Data tersebut mengindikasikan bahwa seluruh siswa di dua TK mendapatkan aktivitas 
pengenalan air, yaitu TK Pedagogia FIP UNY dan Bambini Montessori. Kedua TK tersebut memberikan pembelajaran akuatik pada seluruh siswa, (5) perencanaan pembelajaran akuatik pada empat sekolah disusun dalam bentuk RKS, namun tidak dituliskan secara rinci dalam RKH. Peningkatan materi pembelajaran tergantung pada perkembangan siswa setiap pertemuan. Terdapat satu sekolah yang menyusun RKH untuk pembelajaran akuatik, yaitu Bambini Montessori, (6) proses pengenalan air pada dua sekolah menggunakan model bermain secara terstruktur dan satu sekolah secara tidak terstruktur. Model bermain secara tidak terstruktur adalah membebaskan siswa untuk melakukan aktivitas di air tanpa mendapatkan bimbingan intensif. Guru berada di luar kolam renang untuk mengawasi aktivitas siswa agar keamanan siswa tetap terkontrol. Model pembelajaran teknik yang dilakukan secara berulang-ulang dilakukan oleh dua sekolah, (7) tenaga pengajar akuatik yang memiliki latar belakang keilmuan pendidikan jasmani terdapat pada tiga sekolah, yaitu TK Negeri Pembina Yogyakarta, TK Pedagogia FIP UNY, dan Bambini Montessori. Kangaroo Preschool melibatkan tiga guru kelas untuk menyelenggarakan muatan lokal aktivitas akuatik. TK Negeri 2 Yogyakarta menyelenggarakan muatan lokal aktivitas akuatik tanpa pendampingan guru di dalam kolam renang. Guru berada di luar kolam renang untuk melakukan pengawasan dan pengontrolan aktivitas siswa.

Pada waktu wawancara berlangsung, peneliti menanyakan tanggapan guru kelas apabila diadakan model pengenalan air dalam KBM dengan ketentuan guru kelas sebagai pengajar. Terdapat dua macam jawaban dari kelima guru, yaitu setuju dan tidak setuju. Jawaban tidak setuju diberikan oleh tiga guru, sedangkan dua guru menjawab setuju. Alasan ketiga guru tidak setuju karena guru tidak memiliki keterampilan renang dan belum pernah melakukan pembelajaran di kolam renang. Guru menganggap pembelajaran yang diselenggarakan di kolam renang adalah belajar teknik renang. Guru belum mengetahui bahwa pembelajaran yang dilaksanakan di kolam renang tidak selalu belajar teknik, namun dapat berupa aktivitas pengenalan air melalui bermain.

Berdasarkan analisis hasil observasi dan wawancara peneliti tentang pelaksanaan pengenalan air menunjukkan bahwa pembelajaran yang memuat materi pengenalan air sudah mendapatkan perhatian dari guru TK.
Namun, beberapa sekolah belum memiliki kejelasan tujuan pengenalan air dan standar keselamatan penyelenggaran pembelajaran di air. Pembelajaran akuatik yang bersifat rekreatif maupun menuju prestasi membutuhkan standar operasional beraktivitas di air untuk meminimalisir terjadi kecelakaan di air.

Hasil laporan penelitian Gilchrist, Gotsch, \& Ryan (2004, pp.447-552) menunjukkan selama tahun 2001-2002 diperkirakan terdapat 4.174 orang dirawat di unit gawat darurat (UGD) Amerika Serikat karena mengalami cedera berat akibat tenggelam yang terjadi di tempat rekreasi air buatan. Tenggelam menjadi penyebab kematian kedua pada anak usia 1-14 tahun di Amerika Serikat. Amerika Serikat sebagai negara maju ternyata masih terjadi banyak kasus tenggelam, terutama pada usia anakanak. Jaminan keselamatan beraktivitas di air ternyata tidak hanya tergantung dari ketersediaan fasilitas yang memadai, namun diperlukan keterampilan berenang. Anak membutuhkan pengalaman beraktivitas di air secara aman untuk dapat menerima informasi aktivitas aman dan berbahaya ketika bermain di air.

Indonesia merupakan negara kepulauan yang berarti dekat dengan lingkungan perairan. Wahana wisata air alami maupun buatan banyak berkembang di Indonesia. Pengenalan air perlu diberikan dalam pembelajaran di sekolah sejak dini agar anak mengenal cara aman beraktivitas di air. Manfaat yang didapat adalah meminimalisir terjadi tenggelam di wahana wisata air.

Berdasarkan hasil studi pendahuluan dan studi pustaka, maka kesimpulan peneliti adalah air menyenangkan bagi anak, namun mengandung resiko berbahaya bagi keselamatan anak. Pengenalan air perlu diberikan pada anak sejak dini. Siswa TK kelompok B dapat menjadi sasaran yang tepat untuk mendapatkan aktivitas pengenalan air. Siswa kelompok B memerlukan instruksi yang lebih singkat daripada siswa kelompok A. Secara fisik siswa kelompok B dapat melakukan koordinasi ritme dan kontrol gerak yang lebih baik dari kelompok B. Hal tersebut dikarenakan siswa kelompok B sudah mampu menggabungkan kesadaran ruang dan waktu. Kemampuan ini dibutuhkan dalam aktivitas pengenalan air di sekolah sebab aktivitas yang diberikan adalah bermain di dalam kolam renang dengan ukuran yang tidak luas.

Penelitian ini akan mengembangkan model pengenalan air yang disesuaikan dengan 
kurikulum dan karakteristik siswa TK kelompok B. Model yang dihasilkan diharapkan mampu merangsang perkembangan aspek kognitif, afektif, dan psikomotor siswa untuk mendukung perkembangan dan pertumbuhan siswa. Model dilengkapi dengan aturan keselamatan untuk memperkenalkan pada siswa tentang cara aman bermain di air. Model yang telah dikembangkan diharapkan memberikan referensi bagi guru tentang variasi model pengenalan air sehingga memudahkan guru mengaplikasikan model pengenalan air ke dalam RKH. Guru diharapkan menyelenggarakan model pengenalan air dalam KBM agar semua siswa memiliki pengalaman bermain di air secara aman.

\section{Metode Penelitian}

Penelitian ini merupakan penelitian pengembangan (research and development) untuk menghasilkan produk pendidikan. Dunia pendidikan membutuhkan metode penelitian dan pengembangan untuk meningkatkan kualitas pendidikan. Penelitian dan pengembangan merupakan proses untuk mengembangkan dan memvalidasi produk pendidikan berupa barang, prosedur, maupun metode pembelajaran. Berdasarkan penjelasan Gall, Gall, \& Borg (2003, p.569) bahwa penelitian dan pengembangan menggunakan temuan penelitian untuk merancang prosedur dan produk baru, kemudian secara sistematis diuji di lapangan, dievaluasi, dan disempurnakan sampai memenuhi kriteria tertentu dari unsur efektivitas, kualitas, atau standar yang sama.

Penelitian pendahuluan dilakukan untuk menganalisis pelaksanaan pembelajaran di air bagi siswa TK kelompok B sehingga dihasilkan data analisis kebutuhan. Berdasarkan data analisi kebutuhan, dilakukan pemilihan variabel yang berpotensi dapat dikembangkan. Pengembangan dilakukan untuk menghasilkan produk berupa model pengenalan air bagi siswa TK kelompok B yang disusun dalam buku pedoman. Pengembangan isi dan tujuan model berpedoman pada kurikulum TK kelompok B. Hal tersebut memudahkan guru dalam mengimplementasikan model ke dalam rencana kegiatan harian. Fokus pengembangan model berdasarkan aspek kognitif, afektif, dan psikomotor. Pengembangan pada tahap pemilihan bentuk aktivitas pengenalan air disesuaikan dengan tahap-tahap perkembangan serta karakteristik siswa TK kelompok B.
Pelaksanaan prosedur pengembangan dan penelitian dalam penelitian ini mengadaptasikan langkah-langkah penelitian dan pengembangan pendidikan yang dikembangkan oleh Walter Dick \& Lou Carey. Langkah-langkah penelitian dan pengembangan model Walter Dick \& Lou Carey (Gall, Gall, \& Borg, 2003, p.571) yang harus ditempuh sebagai berikut: (1) menilai kebutuhan untuk mengidentifikasi tujuan, (2) melakukan analisis instruksional, (3) menganalisis peserta didik dan bahan materi, (4) menulis tujuan kinerja, (5) mengembangkan instrumen penilaian produk, (6) mengembangkan strategi instruksional, (7) mengembangkan dan memilih bahan instruksional, (8) desain produk dan melakukan evaluasi formatif terhadap instruksi, (9) merevisi instruksi, dan (10) desain dan melakukan evaluasi sumatif. Kesepuluh langkah tersebut akan menghasilkan produk akhir yang efektif dan dapat diimplementasikan.

Berdasarkan 10 langkah penelitian dan pengembangan tersebut, penelitian ini hanya akan menggunakan 9 langkah, yaitu: (1) menilai kebutuhan untuk mengidentifikasi tujuan, (2) melakukan analisis instruksional, (3) menganalisis peserta didik dan bahan materi, (4) menulis tujuan kinerja, (5) mengembangkan instrumen penilaian produk, (6) mengembangkan strategi instruksional, (7) mengembangkan dan memilih bahan instruksional, (8) desain produk dan melakukan evaluasi formatif terhadap instruksi, dan (9) merevisi instruksi.

Prosedur Penelitian dan Pengembangan

\section{Menilai Kebutuhan untuk Mengidentifikasi Tujuan}

Berdasarkan studi pendahuluan ditemukan asumsi bahwa guru TK belum percaya diri dalam melaksanakan pengenalan air di kolam renang walaupun sekolah memiliki fasilitas kolam renang. Persepsi guru tentang pembelajaran di air adalah guru harus memiliki keterampilan berenang. Hal tersebut menghambat kreativitas guru dalam menyelenggarakan pembelajaran di air. Selain itu, sekolah belum memiliki model pengenalan air secar terstruktur yang dilakukan di kolam renang. Sekolah memerlukan model pengenalan air yang terstruktur untuk dilaksanakan dalam KBM.

Studi pendahuluan dilakukan melalui observasi dan wawancara terhadap 5 guru TK kelompok B di dua TK Negeri di Kota Yogyakarta, satu TK swasta di Kota Yogyakarta, dan 
dua TK swasta di kabupaten Sleman. Selain itu, peneliti melakukan studi pustaka untuk mempelajari kurikulum TK kelompok $\mathrm{B}$, hasil penelitian yang relevan, dan teori yang berkaitan dengan pengenalan air bagi siswa TK kelompok B. Informasi dari hasil observasi, wawancara, dan studi pustaka kemudian dianalisis untuk memfokuskan aspek-aspek yang akan menjadi dasar pengembangan model pengenalan air bagi siswa TK kelompok B. Pengembangan difokuskan pada aktivitas pengenalan air yang mengembangkan aspek kognitif, afektif, dan psikomotor siswa TK kelompok B.

\section{Melakukan Analisis Instruksional}

Analisis intruksional yang dilakukan adalah mengidentifikasi keterampilan khusus yang akan dikembangkan, prosedur pelaksanaan model, dan tugas belajar yang akan diberikan pada siswa TK kelompok B. Berikut analisis yang telah dilakukan, (a) identifikasi bentuk aktivitas (motorik dasar) pengenalan air yang akan digunakan, meliputi aktivitas masuk kolam renang, mengapung, keseimbangan dalam air, gerakan tungkai, dan kontrol nafas, (b) identifikasi sikap dasar (aspek afektif) yang ingin dikembangkan, antara lain percaya diri, mentaati peraturan, mendengarkan instruksi, dan partisipasi aktif, (c) identifikasi aturan keselamatan di kolam renang, prosedur kelas, peraturan permainan, dan pemilihan bahasa instruksi agar mudah dipahami siswa TK kelompok B (aspek kognitif).

\section{Menganalisis Peserta Didik dan Bahan Materi}

Pertama, menganalisis manfaat dan kebutuhan pengenalan air bagi siswa TK kelompok B (usia 5-6 tahun). Kedua, menganalisis karakteristik pertumbuhan dan perkembangan siswa TK kelompok B. Ketiga, menganalisis tingkat pencapain perkembangan aspek kognitif, afektif, dan psikomotor siswa TK kelompok B dalam kurikulum. Keempat, menentukan indikator pencapaian perkembangan siswa TK kelompok B dalam model pengenalan air.

\section{Menulis Tujuan Kinerja}

Penelitian dan pengembangan ini bertujuan untuk menghasilkan produk berupa model pengenalan air bagi siswa Taman Kanak-kanak yang disusun dalam buku pedoman berjudul "Jelajah Air". Sasaran utama model pengenalan air adalah siswa TK kelompok B. Buku pedoman disusun untuk mempermudah guru TK memahami pelaksanaan model dan aplikasi di dalam Rencana Kegiatan Harian (RKH). Setiap model menggunakan tema yang biasa digunakan dalam pembelajaran TK.

\section{Mengembangkan Instrumen Penilaian Produk}

Pengembangan instrumen penilaian produk diawali dengan penyusunan kisi-kisi instrumen. Instrumen penilaian produk akan digunakan untuk menilai draf produk awal, draf sebelum uji coba dengan skala kecil, hasil uji coba dengan skala kecil, dan hasil uji coba dengan skala besar. Penilaian pada draf produk awal sebelum uji coba dengan skala kecil bertujuan sebagai validasi produk. Instrumen Instrumen penilaian produk yang akan dikembangkan terdiri dari 2 jenis yaitu kualitatif dan kuantitatif. Instrumen kualitatif adalah lembar saran perbaikan dan catatan lapangan. Instrumen kuantitatif, yaitu: (1) angket skala nilai validasi; (2) angket skala nilai pedoman observasi permainan; (3) angket skala nilai pedoman observasi keefektifan model dalam pembelajaran; dan (4) rubrik penilaian.

\section{Mengembangkan Strategi Instruksional}

Strategi instruksional yang dimaksud dalam penelitian ini adalah pemilihan strategi untuk memudahkan siswa mencapai tujuan pembelajaran model pengenalan air bagi siswa TK. Model pengenalan air disusun menggunakan pendekatan pembelajaran tematik untuk memudahkan siswa dalam mengintegrasikan nilai-nilai dan pengetahuan yang didapat. Setiap model dirancang sesuai dengan tema yang biasa digunakan dalam pembelajaran TK. Materi penyusunan model berpedoman pada konsep pengenalan air, kurikulum TK kelompok B, dan karakteristik siswa TK kelompok B. Aspek yang dikembangkan dalam model pengenalan air adalah aspek kognitif, afektif, dan psikomotor.

\section{Mengembangkan dan Memilih Bahan Instruk- sional}

Bahan instruksional berupa materi, bahasa, dan desain buku pedoman "Jelajah Air" disusun dalam draf produk awal. Bahasa yang digunakan adalah bahasa Indonesia semi baku. Jenis huruf yang digunakan dalam buku pedoman yaitu Comic Sans MS agar menarik dan tidak terkesan kaku. Desain gambar pada buku pedoman disesuaikan dengan tema setiap model pengenalan air bagi siswa TK dan berwarna. Pemilihan warna menggunakan nuansa air yaitu biru muda dan warna ceria untuk anak. 
Model yang telah disusun dalam draf produk awal dipraktekkan peneliti dalam kegiatan belajar mengajar (KBM) TK kelompok B. Proses praktikum didokumentasikan menggunakan handycame. Rekaman video disimpan di dalam digital versatile disc (DVD). Fungsi dokumentasi video untuk menyamakan persepsi validator tentang pengaturan peralatan dan pelaksanaan model pengenalan air bagi siswa TK.

\section{Merancang dan Melakukan Evaluasi Formatif Terhadap Instruksi}

Evaluasi formatif dilakukan oleh peneliti selama produk dalam masa pengembangan, selain itu berfungsi untuk memberi masukan peningkatan efektivitas produk (Gall, Gall, \& Borg, 2003, p.570). Berikut tahapan evaluasi formatif yang telah dilakukan peneliti.

Pertama, Proses Validasi. Validasi instrumen penelitian model pengenalan air bagi siswa TK menggunakan validasi isi dan expert judgement (validasi ahli). Validasi isi mengacu pada studi pustaka pengenalan air, kurikulum TK kelompok B, dan konsep pertumbuhan dan perkembangan anak. Validasi ahli dilakukan oleh dua ahli dan seorang guru TK kelompok B, yaitu: (1) ahli pendidikan jasmani anak usia dini bernama Dr. Pamuji Sukoco, M.Pd.; (2) ahli aktivitas akuatik bernama Ermawan Susanto, M.Pd.; dan (3) guru TK bernama Meinarsih, S.Pd. langkah-langkah validasi sebagai berikut, (1) peneliti menyampaikan draf produk awal, DVD rekaman video praktikum draf model, dan lembar saran perbaikan kepada ahli materi, (2) ahli materi menyaksikan rekaman video dalam DVD dan menyimak naskah draf model, (3) ahli materi memberikan saran perbaikan secara tertulis di lembar saran perbaikan, (4) peneliti melakukan diskusi dengan validator tentang perbaikan lebih lanjut, (5) peneliti melakukan revisi draf produk awal berdasarkan saran perbaikan dari para ahli, (6) draf yang telah direvisi disampaikan pada ahli materi disertai dengan angket skala nilai untuk validasi, (7) ahli materi melakukan validasi terhadap draf, (8) draf produk awal dinyatakan valid dan dapat dilakukan uji coba lapangan dengan skala kecil apabila sudah mencapai kategori sesuai.

Kedua, Uji Coba dengan Skala Kecil. Peneliti berkoordinasi dengan guru TK kelompok B yang akan mengimplemetasikan draf model pengenalan air. Pelaksanaan uji coba dengan skala kecil bertempat di TK Negeri Pembina Yogyakarta menggunakan subjek 20 siswa putri. Guru kelas berperan sebagai pelaksana proses pembelajaran sesuai dengan draf model. Guru melakukan penilaian aspek kognitif, afektif, dan psikomotor terhadap siswa dalam melaksanakan model pengenalan air. Penilaian tersebut dilakukan untuk mengetahui kemampuan siswa dalam melaksanakan model pengenalan air. Peneliti melibatkan 4 pendamping dalam pelaksanaan model pengenalan air bagi siswa TK. Setiap pendamping bertugas membimbing 5 siswa untuk mematuhi instruksi guru. Dokumentasi dilakukan dengan cara merekam video pelaksanaan uji coba dengan skala kecil. Hasil rekaman video disimpan ke dalam DVD yang digunakan sebagai media observasi para observer.

Observasi dilakukan terhadap substansi model pengenalan air dan keefektifan model dalam proses pembelajaran. Observer dalam uji coba dengan skala kecil merupakan para ahli dan guru yang telah menilai draf produk awal model. Hasil penilaian observasi dan saran perbaikan terhadap uji coba dengan skala kecil digunakan peneliti sebagai referensi perbaikan produk yang akan diujicobakan dengan skala besar.

Ketiga, Uji Coba dengan Skala Besar. Hasil revisi produk diujicobakan ke satu kelas di tiga TK, yaitu TK Negeri Pembina Yogyakarta, TK Negeri 2 Yogyakarta, dan TK Pedagogia FIP UNY. Subjek uji coba dengan skala kecil tidak digunakan dalam uji coba dengan skala besar. Guru utama dalam pelaksanaan model pengenalan air bagi siswa TK adalah guru kelas di TK Negeri Pembina Yogyakarta dan TK Negeri 2 Yogyakarta. Guru utama di TK Pedagogia FIP UNY diperankan oleh guru ekstrakurikuler renang. Guru melakukan penilaian aspek kognitif, afektif, dan psikomotor terhadap siswa dalam melaksanakan model pengenalan air. Rasio jumlah pendamping dengan siswa adalah 1:5. Pelaksanaan uji coba dengan skala besar direkam untuk diobservasi oleh dua ahli, dua guru kelas TK kelompok B, dan satu guru ekstrakurikuler renang TK.

Observasi dilakukan terhadap substansi model pengenalan air dan keefektifan model dalam proses pembelajaran. Saran perbaikan dituliskan di lembar observasi yang telah disediakan oleh peneliti. Hasil penilaian dan saran perbaikan akan digunakan sebagai bahan revisi produk akhir. 


\section{Merevisi Instruksi}

Hasil penilaian dan saran perbaikan terhadap hasil uji coba dengan skala besar serta catatan lapangan digunakan sebagai materi revisi model pengenalan air untuk menyusun produk akhir. Produk akhir yang dihasilkan terdiri dari 6 model. Setiap model terdiri dari latihan pemanasan, inti, dan pelepasan. Model pengenalan air disusun dalam buku pedoman berjudul "Jelajah Air" dilengkapi dengan aturan keselamatan dan contoh rencana kegiatan harian.

\section{Desain Uji Coba}

Draf model pengenalan air disusun secara tertulis kemudian dipraktekkan. Dokumentasi praktikum model pengenalan air digunakan untuk membantu para ahli dan guru dalam memahami pelaksanaan draf model. Para ahli memberikan masukan perbaikan draf dan penilaian. Peneliti melakukan revisi draf dan hasil revisi disampaikan pada validator untuk mendapatkan validasi. Kegiatan selanjutnya adalah pelaksanaan uji coba produk di lapangan. Uji coba produk dilakukan sebanyak dua kali, terdiri dari uji coba dengan skala kecil dan skala besar. Guru berperan sebagai pelaksana proses pembelajaran sesuai dengan draf model. Uji coba yang telah dilakukan akan diobservasi oleh observer yang terdiri dari para ahli materi dan guru TK untuk mengetahui kelayakan model pengenalan air yang telah disusun dengan kenyataan hasil uji coba.

Subjek Coba

Subjek penelitian ditentukan menggunakan teknik purposive sample. Pendapat Sunarno \& Sihombing (2011, p.64) menjelaskan bahwa purposive sample merupakan cara pengambilan sampel berdasarkan pertimbangan dari peneliti. Peneliti memilih dua TK negeri dan satu TK swasta di kota Yogyakarta yang memiliki kolam renang untuk menjadi tempat pengambilan subjek dan pelaksanaan uji coba.

Pelaksanaan uji coba dengan skala kecil menggunakan subjek 20 siswa putri kelompok B TK Negeri Pembina Yogyakarta. Subjek uji coba dengan skala besar menggunakan 17 siswa putra kelompok B TK Negeri Pembina Yogyakarta, 12 siswa putri TK Negeri 2 Yogyakarta, dan 17 siswa TK Pedagogia FIP UNY yang terdiri dari 5 putra dan 12 putri. Beberapa TK melaksanakan pembelajaran air secara terpisah antara siswa laki-laki dan perempuan. Hal tersebut menjadi pertimbangan peneliti dalam pemilihan subjek sehingga diputuskan subjek uji coba pada skala besar menggunakan kelompok putra, putri, dan campuran.

\section{Jenis Data}

Data yang dikumpulan dari penelitian ini ada dua jenis, yaitu data kualitatif dan kuantitatif. Data kualitiatif diperoleh dari: (1) hasil wawancara dengan guru TK; (2) catatan lapangan; dan (3) data saran perbaikan draf model awal dan hasil observasi observer pada pelaksanaan uji coba dengan skala kecil dan besar. Data kuantitatif diperoleh dari: (1) penilaian skala nilai validasi; (2) penilaian pada skala nilai observasi pelaksanaan permainan; (3) penilaian skala nilai observasi keefektifan pelaksanaan model dalam pembelajaran; dan (4) penilaian aspek kognitif, afektif, dan psikomotor siswa.

\section{Instrumen Pengumpulan Data}

\section{Pedoman Umum Wawancara}

Pedoman umum wawancara berisi daftar pertanyaan yang merupakan garis besar tentang hal mendasar yang akan ditanyakan. Pewawancara berhak mengembangkan pertanyaan untuk memperdalam informasi. Pelaksanaan wawancara dilakukan secara terbuka sehingga informan mengetahui bahwa sedang diadakan penelitian dan informan menjadi salah satu sumber informasi. Hal tersebut sesuai dengan pendapat Moleong (2010, p.187), bahwa jenis wawancara terbuka mengharuskan pewawancara membuat kerangka dan garis besar pokok-pokok yang dirumuskan, namun tidak perlu ditanyakan secara berurutan.

\section{Catatan Lapangan}

Catatan lapangan digunakan peneliti untuk mendeskripsikan hasil pengamatan peneliti pada pelaksanaan pembelajaran di air ketika studi pendahuluan. Catatan lapangan tersebut disertai tanggapan peneliti untuk merefleksikan fenomena di lapangan dengan solusi yang akan digunakan. Instrumen catatan lapangan membantu peneliti dalam mengembangkan bentuk aktivitas model pengenalan air.

\section{Angket Skala Nilai}

Angket berisi daftar pernyataan disertai skala nilai digunakan untuk memberikan penilaian pada draf model permainan, observasi pelaksanaan uji coba skala kecil, dan besar. 
Angket dalam pelaksanaan uji coba dengan skala kecil dan besar terdiri dari dua macam, yaitu observasi pelaksanaan model dan keefektifan model dalam proses pembelajaran. Dokumentasi pelaksanaan model permainan disimpan dalam DVD sehingga ahli materi dan guru dapat mengobservasi secara berulang-ulang. Penelitian ini akan menggunakan Skala Likert dengan skala 5 .

Teknik Analisis Data

Teknik analisis data yang digunakan dalam penelitian ini adalah analisis data deskriptif kuantitatif dan kualitatif. Teknik analisis data deskriptif kuantitatif dilakukan pada: (1) hasil penilaian validasi dengan skala nilai ahli materi terhadap draf model permainan sebelum uji coba; (2) data penilaian hasil observasi para observer terhadap model permainan; (3) data hasil observasi observer terhadap keefektifan model pengenalan air dalam proses pembelajaran; dan (4) data hasil penilaian aspek kognitif, afektif, dan psikomotor siswa.

Model yang disusun dianggap layak untuk diujicobakan dengan skala kecil maupun besar apabila secara kuantitatif dihitung skor mencapai standar minimal kelayakan. Norma kategorisasi yang akan digunakan sesuai ketentuan Azwar (2005, p.108) sebagai berikut.

$$
\begin{array}{ll}
X<(\mu-1,0 \sigma) & \text { rendah } \\
(\mu-1,0 \sigma) \leq X<(\mu+1,0 \sigma) & \text { sedang } \\
(\mu+1,0 \sigma) \leq X & \text { tinggi }
\end{array}
$$

Dalam penelitian ini norma kategorisasi rendah diasumsikan sebagai tidak sesuai/ tidak efektif, sedang sebagai cukup sesuai/ cukup efektif, dan tinggi sebagai sesuai/efektif.

Teknik analisis data kualitatif dalam penelitian ini menggunakan model Miles \& Huberman. Pendapat Miles \& Huberman (Ambo Upe \& Damsid, 2010, p.125) menyatakan," Aktivitas dalam analisis data kualitatif dilakukan secara interaktif dan berlangsung secara terus menerus sampai tuntas sehingga datanya sudah jenuh". Aktivitas analisis data model ini adalah reduksi data, penyajian data, dan membuat kesimpulan data.

\section{Hasil Penelitian dan Pembahasan}

Proses revisi model pengenalan air bagi siswa TK telah mengalami 4 kali revisi, yaitu: (1) sebelum validasi, (2) sebelum uji coba produk dengan skala kecil, (3) setelah uji coba dengan skala kecil, dan (4) setelah uji coba dengan skala besar. Tahap revisi keempat merupakan hasil produk akhir model pengenalan air bagi siswa TK yang disusun dalam buku pedoman "jelajah Air" terdiri atas enam permainan dilengkapi dengan rencana kegiatan harian dan rubrik penilaian siswa. Setiap permainan terdiri dari latihan pemanasan, inti, dan pelepasan. Pada latihan pemanasan terdapat satu sampai dua permainan, latihan inti terdiri dari dua permainan, dan latihan pelepasan terdiri dari satu permainan dilanjutkan evaluasi. Alokasi waktu pelaksanaan model pengenalan air bagi siswa TK adalah 5 menit latihan pemanasan, 20 menit latihan inti, dan 5 menit latihan pelepasan. Total waktu pelaksanaan model pengenalan air bagi siswa TK adalah 30 menit. Keenam model pengenalan air disusun berdasarkan tingkat keterampilan yang akan dikenalkan dalam model sebagai berikut:

Permainan Bola Warna

Mengenalkan cara masuk ke kolam, kedalaman air kolam, memasukkan wajah ke dalam air, kontrol nafas, dan berlari di air.

\section{Permainan Air Tumpah}

Menumbuhkan keberanian siswa memasukkan seluruh tubuh ke dalam air

\section{Permainan Harta Karun}

Mengenalkan cara mengapung dengan bantuan (saling berpegangan dengan teman) dan cara memegang pelampung.

Permainan Mandi Pagi

Mengenalkan cara meluncur dengan papan pelampung.

\section{Permainan Hewan Laut}

Mengenalkan cara mengapung tanpa bantuan dan meluncur tanpa pelampung.

Permainan Balap Donat \& Kacang

Mengenalkan cara meluncur dengan pullbuoy dan menggerakkan kedua tungkai sejauh 5 meter.

Berikut merupakan penjelasan kesesuaian setiap permainan model pengenalan air bagi siswa TK terhadap kurikulum dan karakteristik siswa TK kelompok serta aturan keselamatan di air.

\section{Permainan Bola Warna}

Pengenalan air yang diberikan dalam permainan bola warna adalah memperkenalkan 
pada siswa cara masuk ke kolam renang secara aman dan mengenal kedalaman kolam melalui permainan naik kereta api pada latihan pemanasan. Permainan tiup air bertujuan untuk memperkenalkan cara mengontrol nafas di air agar siswa tidak tersedak ketika membenamkan wajah di air dalam permainan-permainan selanjutnya. Pada latihan inti, lebih difokuskan pada pencapaian rasa nyaman dan senang bermain di air dengan permainan yang tidak membutuhkan membenamkan wajah ke air.

Aspek kognitif yang akan ditransfer melalui permainan bola warna adalah membilang bola 1-20 dan mengklasifikasikan bola berdasarkan warna. Berdasarkan kurikulum TK kelompok B, membilang bola 1-20 termasuk dalam tingkat pencapaian perkembangan menyebutkan lambang bilangan 1-10 dengan indikator membilang (mengenal konsep bilangan dengan benda-benda) sampai 20. Mengklasifikasikan bola berdasarkan warna termasuk ke dalam tingkat pencapaian perkembangan mengklasifikasikan benda berdasarkan warna, bentuk, dan ukuran (3 variasi).

Tujuan aspek psikomotor pada permainan bola warna yang meliputi berjalan maju dalam barisan di air dan berlari di air merupakan pengembangan capaian perkembangan motorik kasar, yaitu menggerakkan badan dan kaki dalam rangka keseimbangan, kekuatan, kelincahan, dan melatih keberanian.

Permainan Air Tumpah

Apek kognitif sesuai kurikulum kelompok B yang dikembangkan adalah membedakan benda terapung dan tenggelam, merencanakan urutan pelaksanaan permainan air berantai, mengetahui sifat air turun dari tempat lebih tinggi, dan menghitung benda yang dikumpulkan. Tingkat pencapaian perkembangan yang digunakan meliputi menunjukkan aktivitas yang bersifat ekploratif dan menyelidik, dan menyebutkan lambang bilangan 1-10.

Aspek afektif yang dikembangkan antara lain dapat bekerja sama dengan teman, senang ketika berhasil mengumpulkan benda, dan mentaati peraturan. Tingkat pencapaian perkembangan yang digunakan adalah bersikap kooperatif dengan teman, mengekspresikan emosi sesuai keadaan, dan emahami peraturan.

Aspek psikomotor yang dikembangkan antara lain peregangan dengan senam fantasi, melakukan perpindahan tempat dengan teratur, dan menggambar fantasi gambar datar di permukaan air.

\section{Permainan Harta Karun}

Fokus pengenalan air pada permainan harta karun adalah membenamkan wajah di air, kontrol nafas, mengapung, dan meluncur menggunakan pelampung. Berdasarkan kurikulum TK kelompok B, aspek kognitif yang dikembangkan dalam permainan harta karun adalah mengekspresikan gerakan sesuai dengan syair lagu, mampu memutuskan cara mengambil harta karun dengan tangan, dan membilang 120.

Aspek afektif yang dikembangkan adalah dapat mengambil harta karun sendiri, bekerjasama dengan teman, dapat melaksanakan tugas kelompok, senang ketika mendapatkan sesuatu, dan mentaati peraturan permainan. Tingkat pencapaian perkembangan yang digunakan antara lain memiliki sikap gigih, bersikap kooperatif, mengekspresikan emosi sesuai dengan kondisi yang ada, dan memahami aturan.

Aspek psikomotor yang dikembangkan adalah mengapung, membungkukkan badan, dan mendorong pelampung sambil berjalan/ meluncur. Tingkat pencapaian perkembangan yang digunakan antara lain menirukan gerakan tubuh secara terkoordinasi untuk melatih kelenturan, keseimbangan, dan kelincahan. Perkembangan motorik dasar fundamental yang dikembangkan meliputi gerak lokomotor dan non lokomotor.

\section{Permainan Mandi Pagi}

Fokus pengenalan air pada permainan mandi pagi untuk mengembangkan kesadaran gerak anggota tubuh di air, mengenalkan cara mandi, dan meluncur dengan pelampung sambil menggerakkan tungkai. Dampak yang diharapkan agar siswa lebih siap untuk melakukan koordinasi gerak tubuh dalam model-model pengenalan air selanjutnya. Memotivasi siswa untuk belajar mandi secara mandiri sehingga dapat diaplikasikan dalam kehidupan seharihari.

Aspek kognitif yang dikembangkan dalam permainan mandi pagi adalah mengekspresikan gerakan sesuai dengan syair lagu dan menyusun kepingan puzzle. Tingkat pencapaian perkembangan yang digunakan antara lain menunjukkan inisiatif memilih tema permainan dan memecahkan masalah sederhana dalam kehidupan sehari-hari. Perkembangan kognitif siswa TK kelompok B perlu dirangsang dengan tugas pemecahan masalah sederhana agar terbentuk pola pemecahan masalah dimulai dari 
proses mengingat informasi yang pernah diterima.

Aspek afektif yang dikembangkan dalam permainan mandi pagi adalah dapat bekerja sama dengan teman, saling membantu sesama teman, dan sabar menunggu giliran. Tingkat pencapaian perkembangan yang digunakan, yaitu bersikap kooperatif dengan teman, menunjukkan sikap toleran, dan mengekspresikan emosi sesuai keadaan. Siswa TK kelompok B belajar melalui pembiasaan sehingga budaya antri perlu ditanamkan sejak dini.

Aspek psikomotor yang dikembangkan dalam permainan mandi pagi antara lain senam fantasi, mandi sendiri, meluncur dengan bantuan pelampung, dan menggerakkan tungkai ke atas dan ke bawah. Tingkat perkembangan yang dikembangkan adalah melakukan koordinasi gerakan kaki-tangan-kepala dalam melakukan senam fantasi bentuk meniru, melakukan kegiatan kebersihan diri. dan menirukan gerak tubuh secara terkoordinasi untuk melatih kelenturan, keseimbangan, dan kelincahan. Gerak dasar fundamental yang dikembangkan adalah gerak lokomotif yaitu meluncur dengan bantuan pelampung diikuti gerakan tungkai ke atas dan bawah.

\section{Permainan Binatang Laut}

Fokus pengenalan air dalam permainan binatang laut adalah berjalan dengan posisi tubuh dekat dengan air yaitu gerak menirukan kepiting dan singa laut. Gerak berdiri dan jongkok membenamkan tubuh menirukan gerak ubur-ubur. Mengapung menirukan gerak penyu laut kemudian dilanjutkan meluncur tanpa pelampung menirukan gerak paus dan meluncur diawali dengan loncatan menirukan gerak lumba-lumba.

Aspek kognitif yang dikembangkan sesuai kurikulum TK kelompok B adalah bermain peran binatang laut, memasangkan gambar binatang laut yang sama, dan mampu menentukan cara menghimpit bola sambil berjalan ke samping. Tingkat pencapaian perkembangan yang digunakan antara lain menunjukkan inisiatif bermain peran, mengklasifikasikan benda yang lebih banyak ke dalam kelompok yang sama atau kelompok yang sejenis atau kelompok berpasangan lebih dari 2 variasi, dan memecahkan masalah sederhana sehari-hari.

Aspek afektif yang dikembangkan antara lain memberi dukungan pada teman yang belum berani menirukan gerak binatang laut, dapat bekerjasama dengan teman, mau berbagi lembar kerja, sabar menunggu giliran, dan mentaati peraturan permainan. Tingkat pencapaian perkembangan yang digunakan adalah menunjukkan rasa empati, bersikap kooperatif dengan teman, menunjukkan sikap toleran, mengekspresikan emosi sesuai keadaan, dan memahami peraturan.

Aspek psikomotor yang dikembangkan adalah meniru gerak binatang laut (mengapung, meluncur, dan menggerakkan tungkai tanpa pelampung) dan berjalan ke samping secara berpasangan dengan menghimpit bola. Tingkat pencapaian perkembangan yang digunakan yaitu menirukan gerakan tubuh secara terkoordinasi untuk melatih kelenturan, keseimbangan, dan kelincahan. Gerak dasar fundamental yang dikembangkan merupakan gerak non lokomotor dan lokomotor.

\section{Permainan Balap Donat dan Kacang}

Fokus pengenalan air yang ditekankan dalam permainan balap donat dan kacang adalah meluncur melewati rintangan. Tingkat pencapaian perkembangan yang digunakan apek kognitif sesuai kurikulum kelompok B yang dikembangkan adalah memahami konsep "lebih dari", "kurang dari", dan "paling/ter".

Tingkat pencapaian perkembangan afektif yang dikembangkan meliputi kerjasama kelompok dan memiliki sikap gigih. Aktivitas yang membutuhkan kerjasama kelompok perlu diberikan pada siswa TK kelompok B agar memunculkan sikap kooperatif sehingga tumbuh rasa empati.

Aspek psikomotor yang dikembangkan dalam permainan balap donat dan kacang adalah meloncat dari ketinggian $30-50 \mathrm{~cm}$, meloncat untuk meraih dan melambungkan balon, mendorong donat, dan meluncur. Tingkat pencapaian perkembangan yang digunakan yaitu menirukan gerakan tubuh secara terkoordinasi untuk melatih kelenturan, keseimbangan, dan kelincahan. Gerak dasar fundamental yang dikembangkan meliputi gerak lokomotordan manipulatif.

\section{Simpulan dan Saran}

Model pengenalan air bagi siswa TK sesuai dengan kurikulum dan karakteristik siswa TK kelompok B. Model pengenalan air bagi siswa TK kelompok B efektif dilaksanakan dalam proses pembelajaran karena dapat mentransfer nilai-nilai pada aspek kognitif, afektif, dan psikomotor. Kesesuaian model dengan kurikulum ditandai dengan tujuan aspek kognitif, 
afektif, dan psikomotor berpedoman pada tingkat pencapaian perkembangan anak pada kurikulum TK kelompok B.

Model pengenalan air bagi siswa TK mempertimbangkan keselamatan dengan menggunakan rasio pendamping dengan siswa adalah 1:5 ditambah seorang guru utama. Dengan demikian, guru utama dapat fokus menyampaikan pembelajaran dan seorang pendamping bertanggung jawab membimbing dan mengontrol keselamatan 5 siswa. Kedalaman kolam yang digunakan untuk menyelenggarakan model pengenalan air setinggi $50 \mathrm{~cm}$ sehingga meminimalisir resiko tenggelam.

\section{Daftar Pustaka}

Ambo Upe \& Damsid. (2010). Asas-asas multiple research. Yogyakarta: Tiara Wacana.

Azwar, Saifuddin. (2005). Penyusunan skala psikologi. Yogyakarta: Pustaka Pelajar

Gall, Meredith D., Gall, Joyce P., \& Borg, Walter R. (2003). Educational research: an introduction $\left(7^{\text {th }}\right.$ ed). United States of America: Pearson Inc.

Gilchrist, J., Gotsch, K., \& Ryan, G. (2004). Neofatal and fatal drownings in recreational water settings - United States, 2001-2002. Artikel 203705094. Diambil pada tanggal 20 Mei 2013, dari http://search.proquest.com/docview/203 705094 ? accountid=31324.

Kemendiknas. (2010). Pedoman pengembangan program pembelajaran di taman kanakkanak. Jakarta: Kemendiknas.

Miller, Edward \& Almon, Joan. (2009). Crisis in the kindergarten: why children need to play in school [Versi electronik]. The Education Digest, 75, 42-45.

Moleong, L.J.. (2010). Metodologi penelitian kualitatif (Ed. rev.). Bandung: PT Remaja Rosdakarya.

Sunarno, Agung \& Sihombing, S.D.. (2011). Metode penelitian keolahragaan. Surakarta: Yuma Pustaka. 